\title{
Hydrocortisone-Induced Increase of PDGF $\beta$-Receptor Expression in a Human Malignant Mesothelioma Cell Line
}

\author{
M. A. Versnel, ${ }^{*, 1}$ M. J. Bouts, ${ }^{*}$ A. W. LANGERAK, ${ }^{*}$ TH. H. VAN DER KWAST, $\dagger$ \\ H. C. Hoogsteden, \\ Departments of $*$ Immunology, $\dagger$ Pathology, $\ddagger$ Pulmonary Medicine, and $\S$ Cell Biology and Genetics, Erasmus University and Academic Hospital \\ Dijkzigt, Rotterdam, The Netherlands; and ILudwig Institute for Cancer Research, Uppsala, Sweden
}

The effect of hydrocortisone (HC) on PDGF $\beta$-receptor expression was studied in the human malignant mesothelioma cell line Mero-14. HC was found to induce a time- and dose-dependent increase of PDGF $\beta$-receptor mRNA. Nuclear run off analysis revealed that $\mathrm{HC}$ induced increased transcription of the PDGF $\beta$-receptor gene. The expression of PDGF $\beta$-receptor protein was also elevated by $\mathrm{HC}$ as demonstrated with an immunoblotting assay. However, the number of PDGF-BB binding sites on the cell surface of Mero-14 remained unchanged upon $\mathrm{HC}$ treatment. These results suggest that steroid hormones can regulate PDGF receptor expression in vivo. () 1992 Academic Press, Inc.

\section{INTRODUCTION}

Platelet-derived growth factor (PDGF) is a mitogen for fibroblasts, smooth muscle cells, and glial cells and is composed of two disulfide-bonded polypeptides denoted PDGF A-chain and PDGF B-chain $[1,2]$. Three possible isoforms of PDGF (AA, AB, and $\mathrm{BB}$ ) have been identified [3-5].

Two distinct PDGF receptors, designated PDGF $\alpha$ and PDGF $\beta$-receptor, were identified $[6,7]$ and found to dimerize upon binding of PDGF [8-10]. This can result in three distinct PDGF receptor dimers $(\alpha \alpha, \alpha \beta$, and $\beta \beta$ ) with different specificities for PDGF: $\alpha \alpha$-receptors can be formed by all isoforms, $\alpha \beta$-receptors by PDGF$\mathrm{AB}$ and PDGF-BB, and $\beta \beta$-receptors by PDGF-BB [10, 11]. The PDGF $\alpha$ - and $\beta$-receptors have been cloned and found to be encoded by two different genes mapped to human chromosomes 4 and 5, respectively [12-17].

The type of PDGF receptor that is expressed and the level of this expression could be the decisive factor in PDGF responsiveness. In several chronic inflammatory conditions like psoriasis, atherosclerosis, and rheuma-

\footnotetext{
${ }^{1}$ To whom correspondence and reprint requests should be addressed at Department of Immunology, Erasmus University, P.O. Box 1738, 3000 DR Rotterdam, The Netherlands. Telefax: 31-10436.7601 .
}

toid arthritis induction of PDGF $\beta$-receptor expression was found on vascular and connective tissue cells [1821]. The mechanism of regulation of PDGF receptor expression is still unknown. So far, few data are available on the regulation of PDGF receptor expression. Gronwald et al. [22] found that TGF- $\beta$ decreased the number of PDGF $\alpha$-receptors and increased the number of PDGF $\beta$-receptors in 3 T3 cells. A TGF- $\beta$-induced decrease in PDGF $\alpha$-receptor expression was also reported for human fibroblasts and smooth muscle cells [23]. In addition, PDGF itself induces the synthesis of the PDGF $\beta$-receptor [24]. Embryonal carcinoma cells were found to increase the transcription of the PDGF $\alpha$-receptor gene upon exposure to retinoic acid with or without dibutyryl cyclic AMP [25]. Furthermore, it was recently suggested that the synergistic effect from combinations of cyclic AMP and growth factors on Schwann cells may be due to cyclic AMP-mediated induction of growth factor receptors [26].

Human malignant mesothelioma is a mesodermally derived tumor most frequently found in the pleura. $\mathrm{Hu}$ man malignant mesothelioma cell lines were found to express PDGF $\beta$-receptors, whereas cultured normal mesothelial cells express predominantly PDGF $\alpha$-receptors [27]. Furthermore, expression of PDGF A- and B-chain mRNA was found in malignant mesothelioma cell lines, while normal mesothelial cells expressed PDGF A-chains and had a barely detectable level of PDGF B-chain mRNA [28, 29].

In this paper we describe a time- and dose-dependent increase of PDGF $\beta$-receptor mRNA expression upon addition of hydrocortisone (HC) to the culture medium of the malignant mesothelioma cell line Mero-14. In addition, we studied whether the PDGF $\beta$-receptor mRNA induction was due to increased transcription or differences in RNA stability. Immunoblotting and binding experiments with ${ }^{125}$ I-PDGF were performed to investigate the effect of $\mathrm{HC}$ on the protein level.

\section{MATERIALS AND METHODS}

Cell lines and growth conditions. The isolation of normal and malignant mesothelial cell lines and the characteristics of Mero-14 were described earlier [30, 31]. 
Cells were cultured in F10 medium with $15 \%$ fetal calf serum (FCS), $0.1 \mathrm{mg} / \mathrm{ml}$ streptomycin sulfate (Biochrom KG, Berlin, Germany), and $100 \mathrm{IU} / \mathrm{ml}$ penicillin G sodium (Gist-Brocades, Delft, The Netherlands). The medium was supplemented with $10 \mathrm{ng} / \mathrm{ml}$ epidermal growth factor (EGF; Collaborative Research, Lexington, MA) and/or $0.1,0.2,0.4,0.8$, or $1.6 \mu \mathrm{g} / \mathrm{ml}$ hydrocortisone (Pharma Chemie, Haarlem, The Netherlands) when indicated.

RNA isolation and Northern blot analysis. RNA isolation and Northern blot analysis were performed as described [29]. The filters were washed at $42^{\circ} \mathrm{C}$ to $0.3 \times \mathrm{SSC}$ and exposed to a Fuji-RX film.

Probes. The PDGF $\alpha$-receptor probe was a $1.5-\mathrm{kb}$ EcoR1 fragment [13] and the PDGF $\beta$-receptor probe was a 1 -kb Pst 1 fragment [12]. These fragments correspond to the extracellular domain of the PDGF $\alpha$ - and PDGF $\beta$-receptors, respectively. The GAPDH probe was a 0.7 -kb $E$ coR1-Pst1 fragment [32].

$P D G F$, radiolabeled ligands, and radioreceptor assay. PDGF-AA and PDGF-BB were recombinant material expressed in yeast and were ${ }^{125} \mathrm{I}$-labeled by the chloramine $\mathrm{T}$ and Bolton and Hunter methods, respectively, to specific activities of 80,000 (PDGF-AA) and 50,000 (PDGF-BB) cpm/ng [33].

For the radioreceptor assay, cells were plated in 12 -well plates (Costar, Cambridge, MA). When confluence was reached, the cells were washed with phosphate buffered saline (PBS) and incubated for $24 \mathrm{~h}$ in serum-free F10 medium at $37^{\circ} \mathrm{C}$. Prior to binding, the cells were washed with $1 \mathrm{ml}$ PBS supplemented with bovine serum albumin (BSA; Boehringer, Mannheim, Germany), $1 \mathrm{mg} / \mathrm{ml}$. Binding was performed for $2 \mathrm{~h}$ at $0^{\circ} \mathrm{C}$ in a volume of $350 \mu \mathrm{l}$ PBS-BSA containing $50,000 \mathrm{cpm}$ radiolabeled ligands with or without unlabeled PDGF $(250 \mathrm{ng} / \mathrm{ml})$. After three washes with ice-cold PBS-BSA the cells were lysed in $2 \%$ Triton $\mathrm{X}-100$ in $\mathrm{H}_{2} \mathrm{O} .{ }^{125}$ I-Radioactivity was counted in a gamma counter.

Nuclear run off assay. Nuclei were isolated from $10^{8}$ cells essentially according to Zenke $e t a l$. [34] with the presence of $0.5 \%$ NP-40 in the lysis buffer as the only modification. From each cell line $1-2 \times 10^{7}$ nuclei were used for a nuclear run off analysis, as adapted from Linial et al. [35]. The ultimate concentration of Tris- $\mathrm{HCl}, \mathrm{pH} 8.0$, in the run off buffer was $6 \mathrm{mM}$, while $140 \mu \mathrm{Ci}\left[\alpha-{ }^{32} \mathrm{P}\right] \mathrm{UTP}$ was added. Synthesis of transcripts took place at $30^{\circ} \mathrm{C}$ for $20 \mathrm{~min}$ followed by treatment with $10 \mu \mathrm{g}$ DNase I for $5 \mathrm{~min}$ at $30^{\circ} \mathrm{C}$. After centrifugation, the nuclear RNA pellet was resuspended in a buffer containing $45 \%(\mathrm{v} / \mathrm{v})$ formamide, $0.2 M \mathrm{Na} P_{\mathrm{i}}(\mathrm{pH} 7.2$ ), $1 \mathrm{mM}$ EDTA, 7\% SDS, and 250 $\mu \mathrm{g} / \mathrm{ml}$ yeast $\mathrm{RNA}$.

Plasmid DNA was spotted on nitrocellulose filters with the Schleicher and Schuell slot blot apparatus (S \& S, Dassel, Germany) and immobilized for $2 \mathrm{~h}$ at $80^{\circ} \mathrm{C}$. Subsequently, the filters were hybridized with the labeled RNA for 2 days at $45^{\circ} \mathrm{C}$. After hybridization, filters were washed for $8 \mathrm{~h}$ at $65^{\circ} \mathrm{C}$ in $40 \mathrm{mM} \mathrm{Na} P_{\mathrm{i}}(\mathrm{pH} \mathrm{7.2)}, 1 \%$ SDS interrupted by washing in $2 \times \mathrm{SSC}$ containing RNaseA $(5 \mu \mathrm{g} / \mathrm{ml})$ for $30 \mathrm{~min}$ at $37^{\circ} \mathrm{C}$. Autoradiography was performed at $-80^{\circ} \mathrm{C}$ with $\mathrm{Ko}-$ dak XAR films.

Immunoblotting. Mero-14 cells were cultured until confluence was nearly reached either without $\mathrm{HC}$ or with the addition of 0.4 or $0.8 \mu \mathrm{g} / \mathrm{ml} \mathrm{HC}$. Cells were washed with PBS and harvested in PBS with $0.02 \% \mathrm{NaEDTA}$. For each lane $2 \times 10^{6}$ cells were lysed in a buffer containing $0.5 \%$ Triton $\mathrm{X}-100,0.5 \%$ deoxycholate, $25 \mathrm{mM}$ Tris $-\mathrm{HCl}$, pH 7.5, $150 \mathrm{mM} \mathrm{NaCl}, 10 \mathrm{~m} M$ EDTA, and protease inhibitors. After centrifugation, the lysate was incubated with wheat germ lectin Sepharose 6 MB (WGA; Pharmacia, Uppsala, Sweden) on an end-overend rotator overnight at $4^{\circ} \mathrm{C}$. After washing with lysis buffer the beads were boiled for $5 \mathrm{~min}$ in sample buffer containing $2.5 \%$ SDS. The proteins were separated on a $8 \%$ SDS-polyacrylamide gel and blotted to nitrocellulose. Subsequently, the filter was washed twice in PBS blocked in skim milk and washed three times in PBS, containing $0.2 \%$ Tween. The filter was incubated $2 \mathrm{~h}$ at room temperature in 1:100 diluted PDGFR-3, which recognizes PDGF $\beta$-receptors [36].

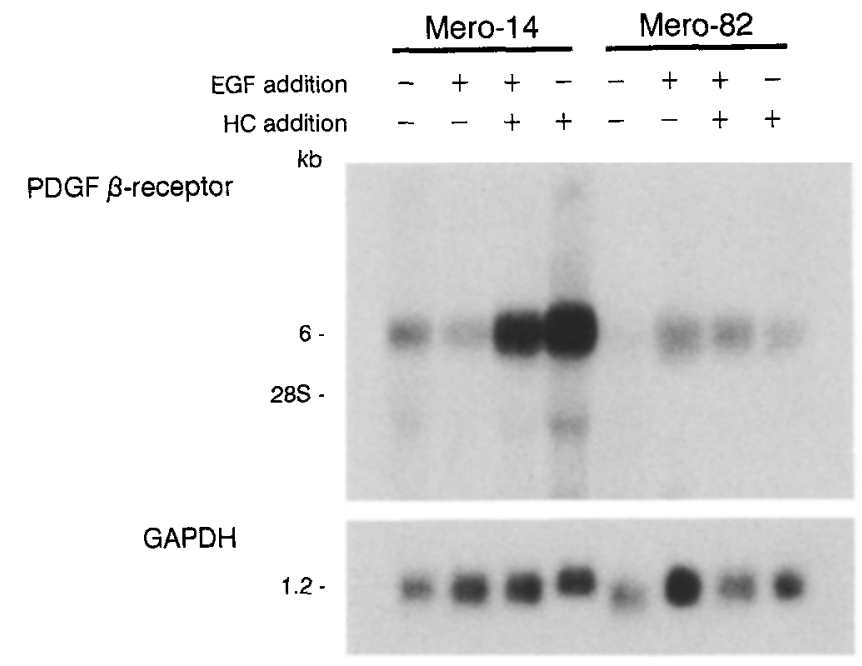

FIG. 1. Northern blot analysis of $25 \mu \mathrm{g}$ total RNA from the malignant mesothelioma cell lines Mero-14 and Mero-82. These cell lines were cultured for $24 \mathrm{~h}$ in medium with $15 \%$ FCS and supplemented with EGF $(10 \mathrm{ng} / \mathrm{ml})$, EGF $(10 \mathrm{ng} / \mathrm{ml})$ plus HC $(0.4 \mu \mathrm{g} / \mathrm{ml})$, or HC $(0.4$ $\mu \mathrm{g} / \mathrm{ml}$ ) only. The filter was hybridized to a ${ }^{32} \mathrm{P}$-labeled PDGF $\beta$-receptor probe and a GAPDH probe.

After washing, goat anti-rabbit-IgG-alkaline phosphatase (Tago, Burlingame, CA) was used as a second step.

Growth kinetics. Triplicate cultures were started in 12 -well plates $\left(25 \times 10^{3}\right.$ cells/culture). After $24 \mathrm{~h}$ the medium was changed to F10 medium with $15 \%$ FCS and $0.4 \mu \mathrm{g} / \mathrm{ml} \mathrm{HC}$ or F10 medium with FCS only. Two days later, the cells were harvested by trypsinization and the number of cells was counted.

\section{RESULTS}

\section{Effect of Hydrocortisone on PDGF $\beta$-Receptor $m R N A$}

According to Connell and Rheinwald [37] normal mesothelial cells have an optimal growth in medium supplemented with EGF and HC. For our experiments concerning PDGF receptor expression, normal mesothelial cells were cultured in medium supplemented with EGF and $\mathrm{HC}$, whereas the malignant mesothelioma cell lines did not require the addition of EGF and HC. In order to investigate whether addition of these supplements affected the PDGF receptor expression in normal and malignant mesothelial cells, seven malignant mesothelioma cell lines were cultured with EGF and HC and normal mesothelial cells without. No difference in the pattern of PDGF receptor expression of normal and malignant cells was observed, except for Mero-14. This malignant mesothelioma cell line was found to increase the level of PDGF $\beta$-receptor mRNA expression upon addition of EGF and $\mathrm{HC}$ to the culture medium (Fig. 1). The effect of EGF only and HC only on PDGF $\beta$-receptor expression in Mero-14 was studied and compared with the malignant mesothelioma cell line Mero-82. These cell lines were cultured for $24 \mathrm{~h}$ in F10 medium with $15 \%$ 


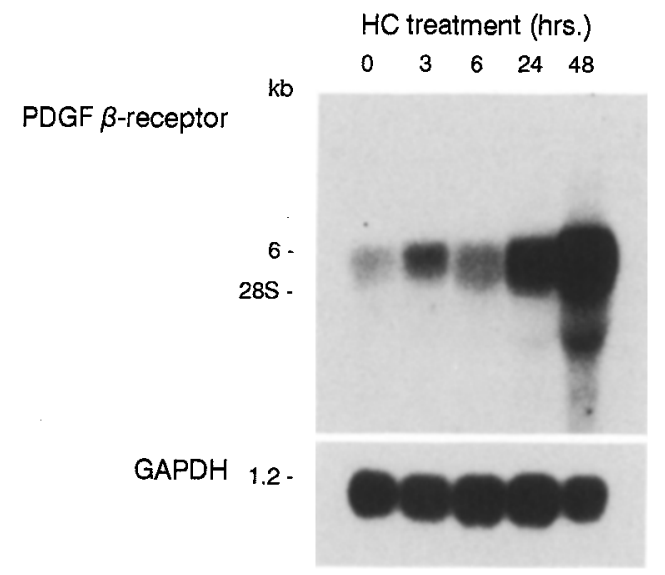

FIG. 2. Northern blot analysis of $25 \mu \mathrm{g}$ total RNA of Mero-14 cells incubated with $\mathrm{HC}(0.4 \mu \mathrm{g} / \mathrm{ml})$ for $3,6,24$, or $48 \mathrm{~h}$. The filter was hybridized to a ${ }^{32} \mathrm{P}$-labeled PDGF $\beta$-receptor probe and a GAPDH probe.

FCS and supplemented with EGF, EGF plus HC, or HC only. After harvesting, RNA was isolated and analyzed for PDGF $\beta$-receptor RNA expression. Mero-14 showed an increase in PDGF $\beta$-receptor mRNA upon the addition of EGF plus HC or HC only (Fig. 1). Addition of EGF only to Mero-14 cells resulted in a similar level of PDGF $\beta$-receptor mRNA expression as F10 medium without supplementation (Fig. 1). Mero-82 was used as a control and did not exhibit a change in PDGF $\beta$-receptor RNA expression upon addition of EGF and/or $\mathrm{HC}$ to the culture medium (Fig. 1).

To determine the time dependence of the increase of PDGF $\beta$-receptor mRNA expression in Mero-14, mRNA was prepared from cells incubated with $\mathrm{HC}$ for $3,6,24$, or $48 \mathrm{~h}$. HC caused an increase of PDGF $\beta$-receptor mRNA in Mero-14, which was clearly detectable from $24 \mathrm{~h}$ after incubation with $\mathrm{HC}$ and was even more pronounced after $48 \mathrm{~h}$ (Fig. 2).

Northern blot analysis of mRNA from Mero-14 incubated with various concentrations of $\mathrm{HC}$ revealed a dose-dependent increase in PDGF $\beta$-receptor mRNA expression from 0.1 to $0.8 \mu \mathrm{g} / \mathrm{ml} \mathrm{HC} \mathrm{(Fig.} \mathrm{3).} \mathrm{In} \mathrm{addition}$ to $\mathrm{HC}$, dexamethasone was found to increase the PDGF $\beta$-receptor mRNA expression in Mero-14 (data not shown). Hybridization of a filter with mRNA from Mero-14 and several other malignant mesothelioma cell lines with a probe for the glucocorticoid receptor revealed the presence of mRNA for this receptor in Mero14 as well as in other malignant mesothelioma cell lines at approximately similar levels (data not shown).

In order to investigate whether the observed $\mathrm{HC}$-induced increase of PDGF $\beta$-receptor mRNA was due to an increased rate of transcription or a difference in cytoplasmic degradation, nuclear run off analysis was performed. Nuclear RNA levels of PDGF A- and B-chain and PDGF $\alpha$ - and $\beta$-receptor in HC-treated Mero-14

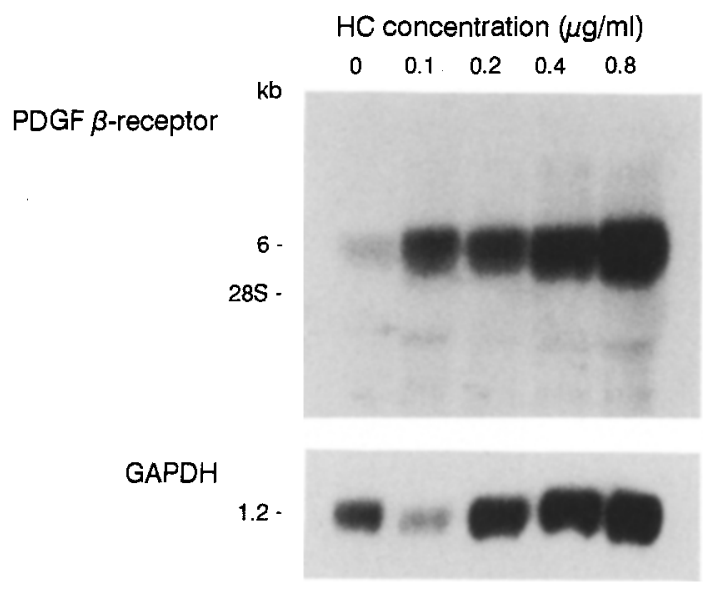

FIG. 3. Northern blot analysis of $25 \mu \mathrm{g}$ total RNA of Mero-14 cells incubated for $24 \mathrm{~h}$ with various $\mathrm{HC}$ concentrations $(0.1,0.2,0.4$, and $0.8 \mu \mathrm{g} / \mathrm{ml}$ ). The filter was hybridized to a ${ }^{32}$ P-labeled PDGF $\beta$-receptor probe and a GAPDH probe.

cells were compared with those in untreated Mero-14 cells (Fig. 4). The quality and expression of the PDGF receptor RNA was related to the constitutively expressed actin gene and pUC was used to exclude the possibility that the observed signal was due to cross hybridization with vector sequences. These experiments revealed that $\mathrm{HC}$-treated Mero-14 cells had an elevated level of nuclear PDGF $\beta$-receptor RNA compared to that of untreated Mero-14 cells. The PDGF $\alpha$-receptor mRNA remained undetectable in HC-treated and untreated Mero-14 cells.

\section{Effect of HC on PDGF $\beta$-Receptor Protein}

To investigate whether the observed increase in PDGF $\beta$-receptor mRNA upon $\mathrm{HC}$ addition results in an elevation of the amount of PDGF $\beta$-receptor protein,

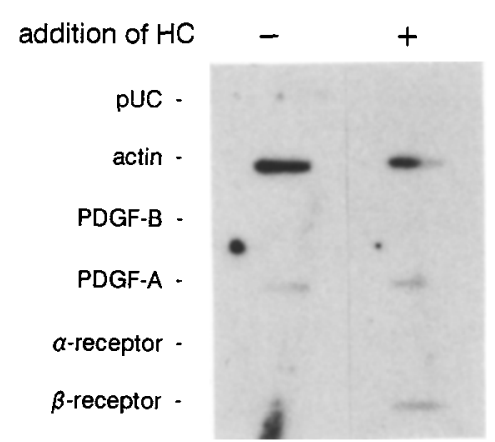

FIG. 4. Nuclear run off analysis of ${ }^{32} \mathrm{P}$-labeled nuclear RNA of Mero-14 cells cultured with or without $\mathrm{HC}$. The radiolabeled transcripts were hybridized to the plasmids pUC, pUC + actin, pUC + PDGF-B, pUC + PDGF-A, pUC + PDGF $\alpha$-receptor, and pUC + PDGF $\beta$-receptor. 


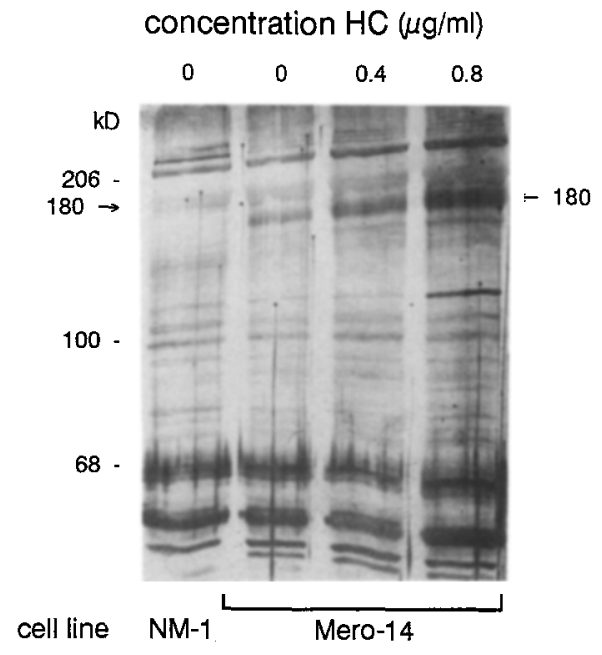

FIG. 5. Detection of PDGF $\beta$-receptors by immunoblotting with the antibody PDGFR-3 in Mero-14 cells cultured for $24 \mathrm{~h}$ without $\mathrm{HC}$ or with 0.4 or $0.8 \mu \mathrm{g} / \mathrm{ml} \mathrm{HC}$. As a control the PDGF $\beta$-receptor negative normal mesothelial cell line NM-1 was used.

immunoblotting and radioreceptor assays were performed.

For immunoblotting, Mero-14 cells were incubated for $24 \mathrm{~h}$ either without $\mathrm{HC}$ or with 0.4 or $0.8 \mu \mathrm{g} / \mathrm{ml} \mathrm{HC}$. The normal mesothelial line NM-1 which has no detectable PDGF $\beta$-receptors was used as a control. After lysis and incubation with WGA-Sepharose, the glycoprotein-enriched lysate was separated by electrophoresis and blotted. The filter was incubated with the PDGF $\beta$-receptor specific antiserum PDGFR-3. As a control, lanes were incubated with normal rabbit serum and PBS. In all three samples of Mero-14 cells, a PDGF $\beta$-receptor specific band of $180 \mathrm{kDa}$ was detected. This band increased in intensity upon the addition of increasing amounts of $\mathrm{HC}$ prior to lysis, showing the most pronounced band when Mero-14 cells were incubated with $0.8 \mu \mathrm{g} / \mathrm{ml} \mathrm{HC} \mathrm{(Fig.} \mathrm{5).} \mathrm{Control} \mathrm{lanes} \mathrm{did} \mathrm{not} \mathrm{reveal}$ a PDGF $\beta$-receptor specific band. These data indicate that $\mathrm{HC}$ increases not only PDGF $\beta$-receptor mRNA but also PDGF $\beta$-receptor protein synthesis in Mero-14.

The level of membrane-associated PDGF $\beta$-receptors in Mero-14 and Mero- 82 cells cultured with and without $\mathrm{HC}$ was compared using a radioreceptor assay with ${ }^{125} \mathrm{I}$ labeled PDGF-AA and ${ }^{125}$ I-labeled PDGF-BB. The binding of ${ }^{125}$ I-labeled PDGF-AA to Mero-14 and Mero-82 cultured without $\mathrm{HC}$ was not significantly over the background. ${ }^{125}$ I-labeled PDGF-BB was found to have a specific binding to Mero-14 and Mero-82, which was lower in the presence of unlabeled PDGF-BB (Fig. 6). These results are in agreement with earlier experiments with a panel of malignant mesothelioma cell lines [27].

Addition of $0.4 \mu \mathrm{g} / \mathrm{ml} \mathrm{HC}$ to Mero-14 and Mero-82 24 $\mathrm{h}$ prior to binding experiments did not reveal an increase in the specific binding of either ${ }^{125}$ I-labeled
PDGF-AA or ${ }^{125}$ I-labeled PDGF-BB compared to cells cultured without $\mathrm{HC}$. These results suggest that the increase in synthesis of PDGF $\beta$-receptor protein expression after $24 \mathrm{~h} \mathrm{HC}$ treatment does not result in a net increased cell surface expression of PDGF $\beta$-receptors. An alternative possibility is that $\mathrm{HC}$ causes also a decrease in receptor affinity. This has not been excluded.

\section{Proliferation of Malignant Mesothelioma Cell Lines in the Presence of $H C$}

We investigated whether the addition of $\mathrm{HC}$ also affected the proliferation of malignant mesothelioma cell lines. Four malignant mesothelioma cell lines were grown in the presence of $0.4 \mu \mathrm{g} / \mathrm{ml} \mathrm{HC}$ for 48 and $72 \mathrm{~h}$, followed by counting of the cell numbers. The proliferation of all four investigated malignant mesothelioma cell lines (Mero-14, $-41,-48 b$, and -82 ) was found to be inhibited compared to cells grown without HC. The percentage inhibition after 48 and $72 \mathrm{~h}$ varied between 20 and 31 (Table 1).

\section{DISCUSSION}

This paper shows that $\mathrm{HC}$ enhances the PDGF $\beta$-receptor mRNA and protein synthesis in the human malignant mesothelioma cell line Mero-14 in a time- and dose-dependent manner. Nuclear run off analysis revealed that the HC-induced effect on PDGF $\beta$-receptor mRNA expression was due to an increased transcription rate of the PDGF $\beta$-receptor gene. In contrast, PDGF $\alpha$-receptor mRNA was undetectable with or without $\mathrm{HC}$ addition.

In a previous paper we described expression of the PDGF A- and B-chain genes in a panel of malignant mesothelioma cell lines including Mero-14 [32]. These cell lines were found to express PDGF $\beta$-receptors [25]. Coexpression of PDGF B-chain and PDGF $\beta$-receptors is thus common in malignant mesothelioma cell lines and suggests that autocrine growth stimulation involving PDGF may be important in the transformation process. In the case of the Mero-14 cell line, HC stimulation might thus, under certain conditions, potentiate an autocrine loop, by stimulation of PDGF $\beta$-receptor synthesis. HC treatment did not affect the PDGF B-chain mRNA expression in Mero-14 cells (data not shown).

The effect of $\mathrm{HC}$ on PDGF $\beta$-receptor expression in Mero-14 was detected on the mRNA and protein level, whereas no increase of membrane bound receptors was found in the receptor binding assay. It should be noted, however, that the amount of PDGF receptors at the cell surface is dependent on the balance between synthesis and degradation of receptors. In Mero- 14 cells, the degradation is likely to be accelerated by the endogenous production of PDGF, which is likely to induce an increased internalization and degradation of receptors: 


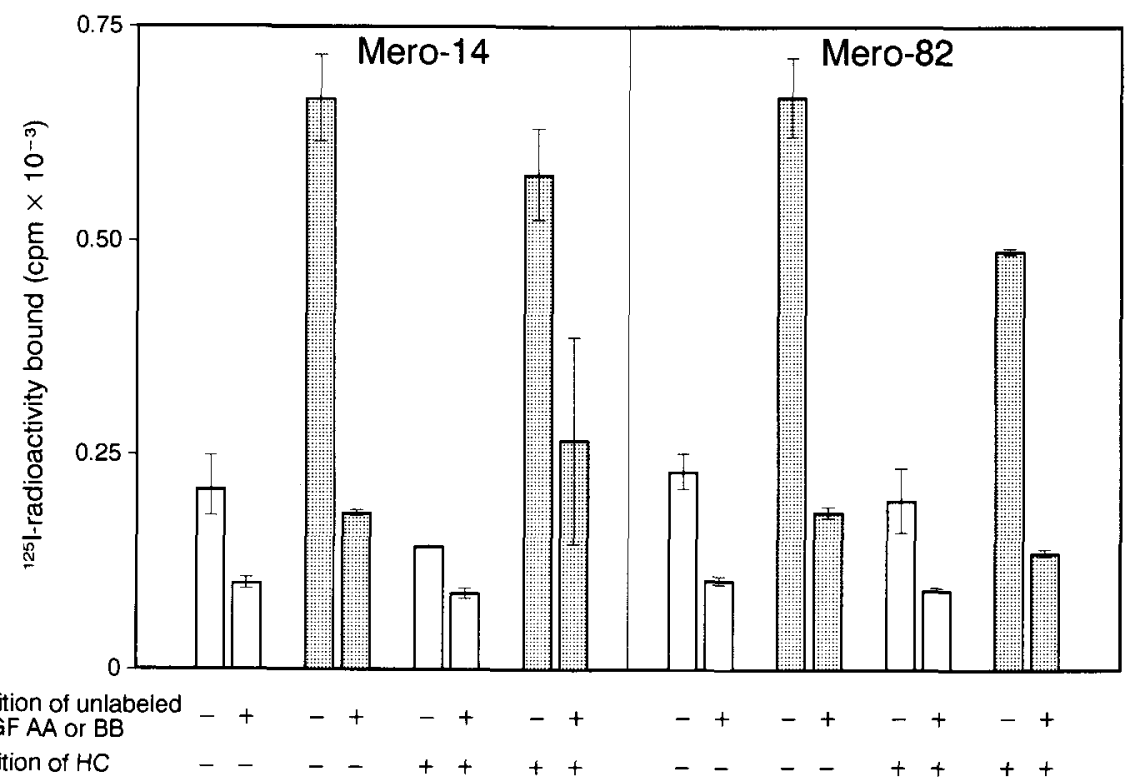

FIG. 6. Binding of ${ }^{125}$ I-PDGF-AA (open bars) and ${ }^{125}$ I-PDGF-BB (stippled bars) in the absence ( - ) or presence $(+)$ of unlabeled ligand to Mero-14 cells cultured for $24 \mathrm{~h}$ without $(-)$ or with $\mathrm{HC}(+)(0.4 \mu \mathrm{g} / \mathrm{ml})$.

whether the degradation rate is affected by $\mathrm{HC}$ treatment remains to be determined.

Glucocorticoids have been shown to stimulate or inhibit cell proliferation in a variety of cell culture systems. We demonstrated that $\mathrm{HC}$ inhibited the growth of four human malignant mesothelioma cell lines including Mero-14. The mechanism for inhibition remains to be elucidated. Clearly, however, $\mathrm{HC}$ affects growth of Mero-14 cells in more than one way; whereas the induction of PDGF $\beta$-receptors would be expected to stimulate growth, the net effect during the in vitro conditions studied in this communication is growth inhibition.

$\mathrm{HC}$ is a glucocorticoid that, upon binding to the glucocorticoid receptor, regulates transcription of genes that have a glucocorticoid responsive element (GRE) [38]. Since the promoter region of the PDGF $\beta$-receptor gene has not yet been characterized, it is not known

\section{TABLE 1}

Inhibition of the Proliferation of Malignant Mesothelioma Cell Lines upon Addition of $\mathrm{HC}$ to the Culture Medium

\begin{tabular}{lcc} 
& \multicolumn{2}{c}{ Culture period } \\
\cline { 2 - 3 } Cell line & $48 \mathrm{~h}^{a}(\%)$ & $72 \mathrm{~h}^{a}(\%)$ \\
\hline Mero-14 & 22 & 25 \\
Mero-41 & 25 & 30 \\
Mero-48b & 31 & 20 \\
Mero-82 & 28 & 30 \\
\hline
\end{tabular}

${ }^{a}$ At 48 and $72 \mathrm{~h}$ after addition of $\mathrm{HC}$ the cells were harvested and counted. Data presented are the mean of two independent experiments. whether it contains a GRE. It was suggested earlier by Terracio et al. [39] that the observed expression of PDGF $\beta$-receptor on cells of the endometrium may be steroid hormone dependent. Although it cannot be excluded that the effect of $\mathrm{HC}$ is directly on PDGF- $\beta$ receptor transcription, an indirect effect seems more likely. This is supported by the observation that $24 \mathrm{~h}$ $\mathrm{HC}$ treatment is necessary for a detectable increase in PDGF $\beta$-receptor mRNA, which is rather long for a direct effect of $\mathrm{HC}$ on PDGF- $\beta$ receptor gene expression. For the insulin receptor, for instance, it has been described that $\mathrm{HC}$ can induce an increase in specific receptor mRNA within $2 \mathrm{~h} \mathrm{[40].} \mathrm{Furthermore,} \mathrm{it} \mathrm{was} \mathrm{re-}$ cently reported by Wang et al. [25] that embryonal carcinoma cells after retinoic acid addition increase their PDGF $\alpha$-receptor RNA expression within $4 \mathrm{~h}$ [25].

From seven investigated malignant mesothelioma cell lines only Mero-14 showed increased PDGF $\beta$-receptor expression upon culturing in medium supplemented with HC. It is unclear why of seven investigated malignant mesothelioma cell lines that all express PDGF $\beta$ - and glucocorticoid receptors, only Mero-14 cells increased their PDGF $\beta$-receptor expression upon $\mathrm{HC}$ addition. This may suggest that a cofactor is involved which is activated in Mero-14 cells only. All malignant mesothelioma cell lines have abnormal karyotypes with multiple numerical and structural abnormalities [30, 31]. Comparison of the karyotype of Mero-14 with the other malignant cell lines did not reveal an aberration that could be involved in the $\mathrm{HC}$-induced PDGF $\beta$-receptor expression.

In conclusion, we have demonstrated that $\mathrm{HC}$ induces an increase of PDGF $\beta$-receptor mRNA and protein in 
the malignant mesothelioma cell line Mero-14. This increase was found to be due to an elevated transcription of the PDGF $\beta$-receptor gene. Our results suggest that regulation of PDGF receptor expression in vivo may be elicitated by steroid hormones.

We are grateful to Prof. Dr. R. Benner for his continuous support and Ms. E. Postma and Mr. M. Delahaye for their advice and technical assistance. Ms. H. Vietsch is acknowledged for the immunoblotting experiments and Mr. T. M. van Os for excellent photographic assistance. Dr. L. Claesson-Welsh is acknowledged for generously providing the PDGF $\alpha$ - and $\beta$-receptor probes and Mrs. H. J. Elsenbroek-de Jager for typing the manuscript. This work was supported by the Dutch Cancer Society.

\section{REFERENCES}

1. Heldin, C.-H., and Westermark, B. (1990) Cell Regul. 1, 555566.

2. Raines, E. W., Bowen-Pope, D. F., and Ross, R. (1990) in Peptide Growth Factors and Their Receptors, Handbook in Experimental Pharmacology (Sporn, M. B., and Roberts, A. B., Eds.), Vol. 95, part 1, pp. 173-262. Springer-Verlag, Heidelberg.

3. Heldin, C.-H., Johnsson, A., Wennergren, S., Wernstedt, C., Betsholtz, C., and Westermark, B. (1986) Nature 319, 511-514.

4. Hammacher, A., Hellman, U., Johnsson, A., Östman, A., Gunnarsson, K., Westermark, B., Wasteson, Å., and Heldin, C.-H. (1988) J. Biol. Chem. 263, 16,493-16,498.

5. Stroobant, P., and Waterfield, M. D. (1984) EMBO J. 3, 29632967.

6. Heldin, C.-H., Bäckström, G., Östman, A., Hammacher, A., Rönnstrand, L., Rubin, K., Nister, M., and Westermark, B. (1988) EMBO J. 7, 1387-1393.

7. Hart, C. E., Forstrom, J. W., Kelly, J. D., Seifert, R. A., Smith, R. A., Ross, R., Murray, M., and Bowen-Pope, D. F. (1988) Science 240, 1529-1531.

8. Heldin, C.-H., Ernlund, A., Rorsman, C., and Rönnstrand, L. (1989) J. Biol. Chem. 264, 8905-8912.

9. Seifert, R. A., Hart, C. E., Phillips, P. E., Forstrom, J. W., Ross, R. Murray, M. J., and Bowen-Pope, D. F. (1989) J. Biol. Chem. 264, 8771-8778.

10. Bishayee, S., Majumdar, S., Khire, J., and Das, M. (1989) J. Biol. Chem. 264, 11,699-11,705.

11. Hammacher, A., Mellström, K., Heldin, C.-H., and Westermark, B. (1989) EMBO J. 8, 2489-2495.

12. Claesson-Welsh, L., Eriksson, A., Morén, A., Severinsson, L., Ek, B., Östman, A., Betsholtz, C., and Heldin, C.-H. (1988) Mol. Cell. Biol. 8, 3476-3486.

13. Claesson-Welsh, L., Eriksson, A., Westermark, B., and Heldin, C.-H. (1989) Proc. Natl. Acad. Sci. USA 86, 4917-4921.

14. Gronwald, R. G. K., Grant, F. J., Haldeman, B. A., Hart, C. E., O'Hara, P. J., Hagen, F. S., Ross, R., Bowen-Pope, D. F., and Murray, M. J. (1988) Proc. Natl. Acad. Sci. USA 85, 3435-3439.

15. Matsui, T., Heidaran, M., Mibi, T., Popescu, N., La Rochelle, W., Kraus, M., Pierce, J., and Aaronson, S. (1989) Science 243, $800-803$.

16. Stenman, G., Eriksson, A., and Claesson-Welsh, L. (1989) Genes, Chromosomes Cancer 1, 155-158.
17. Yarden, Y., Escobedo, J. A., Kuang, W.-J., Yang-Feng, T. L., Daniel, T. O., Tremble, P. M., Chen, E. Y., Ando, M. E., Harkins, R. N., Francke, U., Fried, V. A., Ullrich, A., and Williams, L. T. (1986) Nature 323, 226-232.

18. Rubin, K., Tingström, A., Hansson, G. K., Larsson, E., Rönnstrand, L., Klareskog, L., Claesson-Welsh, L., Heldin, C.-H., Fellström, B., and Terracio, L. (1988) Lancet 1, 1353.

19. Majesky, M. W., Reidy, M. A., Bowen-Pope, D. F., Hait, C. E., Wilcox, J. N., and Schwartz, S. M. (1990) J. Cell Biol. 111, 21492158.

20. Krane, J. F., Murphy, D. P., Gottlieb, A. B., Carter, M., Hart, C. E., and Krueger, J. G. (1991) J. Invest. Dermatol. 96, 983-986.

21. Reuterdahl, C., Tingström, A., Terracio, L., Funa, K., Heldin, C.-H., and Rubin, K. (1991) Lab. Invest. 64, 321-329.

22. Gronwald, R. G. K., Seifert, R., and Bowen-Pope, D. F. (1989) J. Biol. Chem. 264, 8120-8125.

23. Battegay, E. J., Raines, E. W., Seifert, R. A., Bowen-Pope, D. F., and Ross, R. (1990) Cell 63, 515-524.

24. Eriksson, A., Nistér, M., Leveen, P., Westermark, B., Heldin, C.-H., and Claesson-Welsh, L. (1991) J. Biol. Chem. 266, 21,138-21,144.

25. Wang, C., Kelly, J., Bowen-Pope, D. F., and Stites, C. (1990) Mol. Cell Biol. 10, 6781-6784.

26. Weinmaster, G., and Lemke, G. (1990) EMBO J. 9, 915-920.

27. Versnel, M. A., Claesson-Welsh, L., Hammacher, A., Bouts, M. J., van der Kwast, Th. H., Eriksson, A., Willemsen, R., Weima, S. M., Hoogsteden, H. C., Hagemeijer, A., and Heldin, C.-H. (1991) Oncogene 6, 2005-2011.

28. Gerwin, B. I., Lechner, J. F., Reddel, R. R., Roberts, A. B., Robbins, K. C., Gabrielson, E. W., and Harris, C. C. (1987) Cancer Res. 47, 6180-6184.

29. Versnel, M. A., Hagemeijer, A., Bouts, M. J., van der Kwast, Th. H., and Hoogsteden, H. C. (1988) Oncogene 2, 601-605.

30. Versnel, M. A., Bouts, M. J., Hoogsteden, H. C., van der Kwast, Th. H., Delahaye, M., and Hagemeijer, A. (1989) Int. J. Cancer 44, 256-260.

31. Versnel, M. A., Hoogsteden, H. C., Hagemeijer, A., Bouts, M. J., van der Kwast, Th. H., Delahaye, M., Schaart, G., and Ramaekers, F. C. S. (1989) Cancer Genet. Cytogenet. 42, 115-128.

32. Benham, F. J., Hodgkinson, S., and Davies, K. E. (1984) EMBO J. 3, 2635-2640.

33. Östman, A., Bäckström, G., Fong, N., Betsholtz, C., Wernstedt, C., Hellman, U., Westermark, B., Valenzuela, P., and Heldin, C.-H. (1989) Growth Factors 1, 271-281.

34. Zenke, M., Kahn, P., Disela, C., Vennström, B., Leutz, A., Keegan, K., Hayman, M. J., Choi, H.-R., Yew, N., Engel, J. D., and Beug, H. (1988) Cell 52, 107-119.

35. Linial, M., Gunderson, N., and Groudine, M. (1985) Science 230, 1126-1132.

36. Claesson-Welsh, L., Hammacher, A., Westermark, B., Heldin, C.-H., and Nistér, M. (1989) J. Biol. Chem. 264, 1742-1747.

37. Connell, N. D., and Rheinwald, J. G. (1983) Cell 34, 11-24.

38. Evans, R. M. (1988) Science 240, 889-895.

39. Terracio, L., Rönnstrand, L., Tingström, A., Rubin, K., Claesson-Welsh, L., Funa, K., and Heldin, C.-H. J. (1988) Cell. Biol. 107, 1947-1957.

40. Rouiller, D. G., McKeon, C., Taylor, S. I., and Gorden, P. (1988) J. Biol. Chem. 263, 13,185-13,190. 